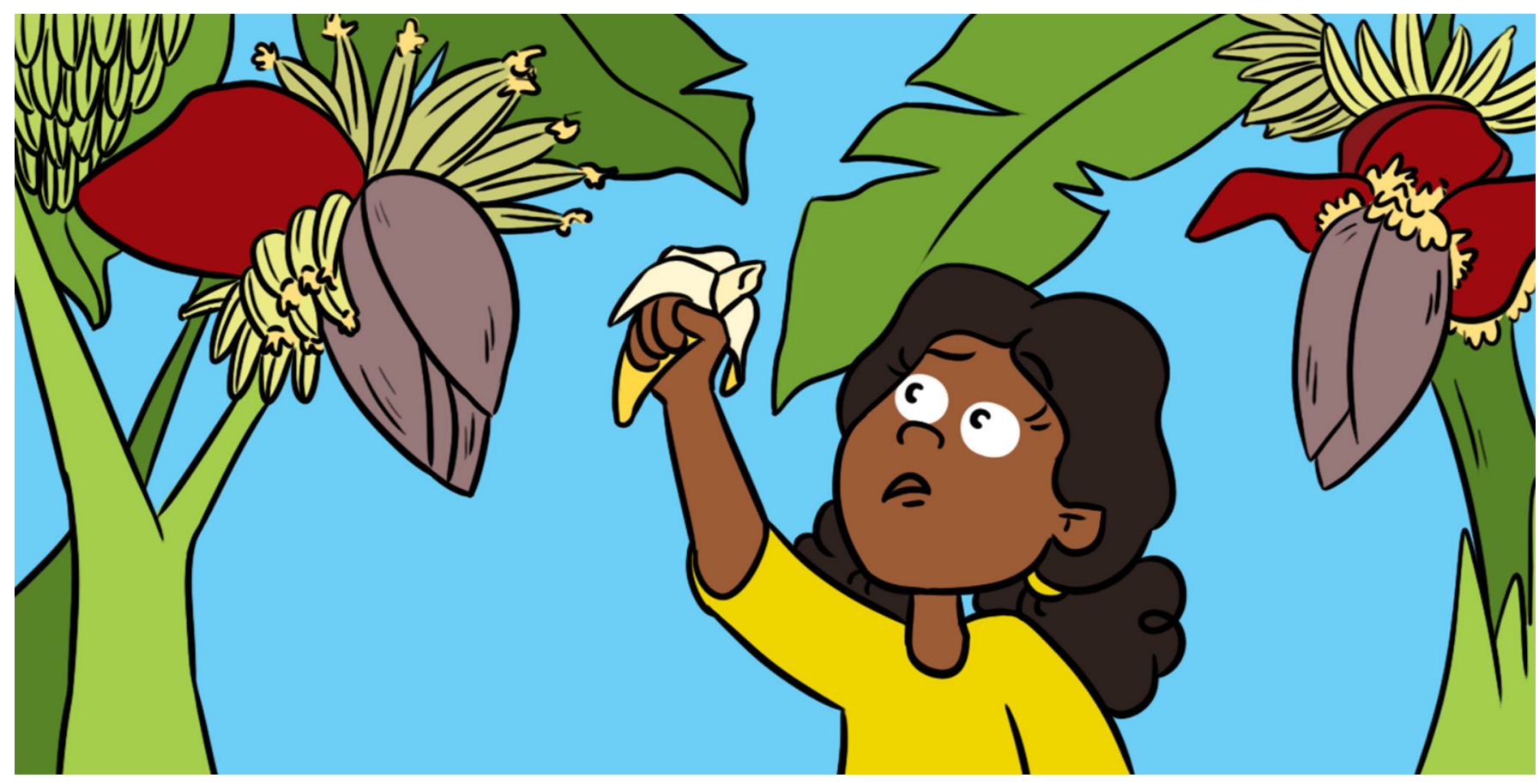

\title{
HOW DO BANANA FLOWERS DEVELOP?
}

\section{Bruce K. Kirchoff ${ }^{1 *}$ and Riva A. Bruenn ${ }^{2}$}

${ }^{1}$ Department of Biology, University of North Carolina at Greensboro, Greensboro, NC, United States Department of Science and Biotechnology, Berkeley City College, Berkeley, CA, United States

YOUNG REVIEWER:

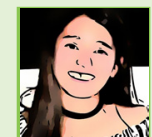

SOFÍA

AGE: 14
Banana flowers form deep within the stem of the banana plant, long before they appear to us. The flowers occur in groups called hands, and the hands are arranged into larger clusters of flowers. Both the number of flowers in a hand and their pattern of development are different between cultivated (supermarket) and wild species of bananas. In supermarket bananas, each hand has many flowers, and the flowers develop in a regular pattern from right to left. In the wild species called the hairy banana, there is no regular pattern of flower formation. Flowers of the hairy banana are never formed in the regular right-to-left manner as found in the supermarket species. This is surprising and illustrates an important point about science: we do not always get the answers we expect. When they are first formed, banana flowers have no parts. They go through a process to form the flower parts that we see. After we describe how this takes place, we give you a project, so you can see how this happens on your own. You will work as a scientist to discover the pattern of development in banana flowers. 


\section{FLOWER}

\section{DEVELOPMENT}

Flower development is the process through which flowers come into being. It is like the development of a baby in its mother's womb in that it begins with a bunch of cells with no particular form, and ends with a fully formed organism or, in this case with a flower.

Figure 1

(A) Clusters of banana fruits arranged in groups called hands. Each hand contains many bananas, which develop from the female part of the flower, the ovary (see B). The hands of flowers are born under a modified leaf that protects them while they are young (see B). Later, when the bananas are nearly ripe, the modified leaf falls off, leaving a scar.

(B) A flower cluster with open female flowers and male flowers inside the big red bud at the center of the picture. The male flowers are formed separately, after the female.

\section{WHERE DO BANANAS COME FROM?}

Close your eyes and imagine a banana. You are probably seeing a long, yellow, curved fruit you can easily peel. Inside the peel, the fruit is lightly colored, soft, and sweet. This is a Cavendish banana, the type that is most often sold around the world. There are over 1,000 varieties, or types, of bananas eaten around the world. Many of these varieties look and taste very different from the ones you see in supermarkets. Bananas are an important food crop. In 2015, over 100 million tons of bananas were grown worldwide [1]. Even though bananas are such a popular and important food, there are still many mysteries about the plants that make them. For example, until my (Dr. Kirchoff's) work, no one had ever completely described the pattern of how banana flowers form. The banana fruit you eat comes from part of the banana flower. The process of flower formation is called flower development.

One of the mysteries of banana flower development is how the plant first forms its flowers. Banana flowers form deep within the stem of the plant and get hidden within the bases of the leaves. By the time the stem appears above the leaves, the flowers have nearly finished growing. You cannot see the first stages of flower development without cutting apart the banana plant. In 1953, one of my scientific teachers, Dr. Abraham Fahn, described how flowers form in the Dwarf Cavendish banana plant, a plant with bananas very similar to the type you eat [1, 2]. Dr. Fahn described how each group of flowers forms. In bananas, these groups are called "hands," because the bananas resemble fingers (Figure 1). The first flower is formed on the right side of the hand (Figure 2A). The rest of the flowers form in a zigzag pattern, back and forth between the top and the bottom rows. Similar patterns have been described in related banana species $[3,4]$.

While Fahn's work was excellent, his results might not be true for other species of banana plants. Science depends on many sources of evidence, not just one. I, therefore, decided to check Fahn's results by studying a wild species of banana, one that had not been bred for

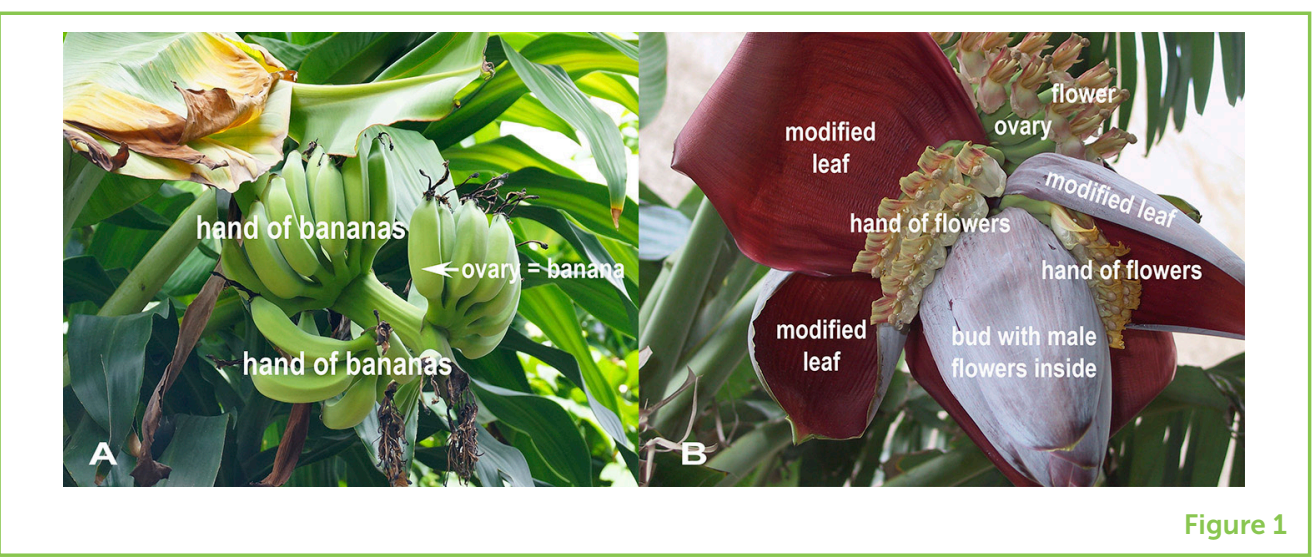


Figure 2

(A) In supermarket bananas, the first flower (labeled 1) forms on the right side of the hand. After that, the flowers develop in a zigzag pattern from right to left. " 2 " represents the second flower that forms, etc. The base of the hand continues to grow during this time, which makes room for the new flowers.

(B) The patterns of flower formation found in the hairy banana. There is little growth of the base of the hand during flower formation in the hairy banana.

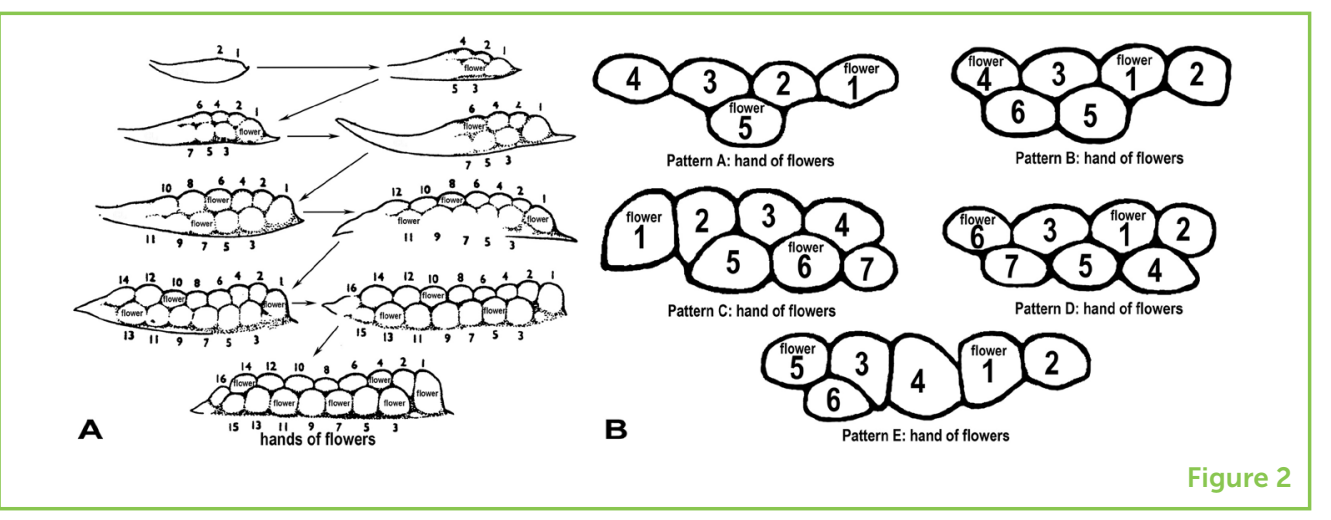

supermarkets. While I was at it, I decided to carry out a thorough study of the other stages of flower development, so that there would be a complete description for other scientists. I did not do this work alone. Many students contributed to the results that are presented here. Their names are listed in the Acknowledgments.

\section{WILD BANANA PLANTS MAKE FLOWERS IN FIVE DIFFERENT PATTERNS}

Surprisingly, the banana plant I studied, the hairy banana (Musa velutina'), did not make flowers in the same way as the bananas Fahn studied. I found five different patterns (Figure 2B). Two of these are similar to Fahn's result (Figure 2B, patterns $\mathrm{A}, \mathrm{B}$ ). Others are very different (Figure 2B, patterns $C-E)$. In one pattern, the order flowers form is the opposite of what Fahn described (Figure 2B, pattern C). In this pattern, flowers form from left to right, instead of from right to left. I also found different versions of each pattern, giving a total of 29 different patterns.

If you compare the two parts of Figure 2, then you will see that the supermarket banana that Fahn studied has many more flowers than the hairy banana. The hairy banana only has 5-7 flowers in a hand. That means, there are 25-40 flowers per plant, arranged in 5-7 hands. The supermarket banana can produce up to 400 flowers (and bananas!) arranged in 20 hands. This may be why the two species make flowers in different ways - the hairy banana may make flowers differently because it has so few flowers. If this is true, Fahn's results might be correct for most banana species. To test this, we need to study even more banana species in the future. This is often the case in science. We design a study to answer a simple question only to find that the answer we get is more complicated and interesting than we expected. Research often results in new questions and new studies.

Musa velutina is the scientific name of the hairy banana 


\section{SEPALS}

The outermost flower parts. In most plants, sepals protect the flower when it is in bud.

\section{PETALS}

The flower parts right inside the sepals. In most plants, petals attract insects and birds (and people!) to the flowers. The insects help plants reproduce by moving pollen from one flower to another. People admire the flowers, and sometimes cut them to put in vases.

\section{STAMENS}

The male part of the plant. Stamens contain sacs with many pollen grains inside. The Latin root stam- means anything that stands upright. The stamens stand upright (Figure 3A).

\section{Figure 3}

(A) A hand of female banana flowers, each with five fused sepals and petals, and one petal that remains unfused. The female flowers have stamens (male parts), but the stamens do not produce good pollen grains. Pollen grains contain the sperm. The female part of the flower has an ovary, which will develop into the banana fruit. The style and stigma function in fertilization, which leads to the formation of the banana fruit. (B) A cut fruit of a wild species like the hairy banana, filled with hard seeds. These fruits cannot be eaten.

\section{FLOWER STRUCTURE AND DEVELOPMENT IN THE HAIRY BANANA}

Almost all flowers, including banana flowers, have four types of parts: sepals, petals, stamens, and the ovary (Figure 3A). The sepals and petals are the outer parts of the flower and are often colorful (though not in banana flowers). The stamens are the male parts. The ovary is the female part. In bananas, the ovary develops into the banana fruit. In the hairy banana, the ovary grows into a banana that is full of seeds and is not edible (Figure 3B).

Banana flowers come in two forms, male and female. Both male and female flowers have sepals and petals (Figures 3, 4). There are three sepals and three petals (Figure 4D). Two of the sepals and all of the petals are fused together, whereas one petal is free (Figures 3A, 4B). Male flowers have normal stamens that form normal pollen. The pollen functions in plant reproduction, but the male banana flowers never form banana fruits. Female flowers have an ovary that develops into a banana fruit (Figures 1,3 ), but the stamens of female flowers do not make pollen.

The stamens are in two circles, with three stamens in the outer circle and two stamens in the inner circle. These five stamens are present in both male and female flowers (Figure 3A), though they have no function in the female flowers.

The female part of the flower has three sections. If you cut a banana crosswise, then you can often see these sections. You can even separate a banana into three long sections. If you try this, then use a banana that is still a bit green.

In both male and female flowers, the parts of the flower form in this order: two sepals form first, followed by a petal, then three stamens, the other two petals and stamens, and then the third and final sepal (Figure 5). The ovary forms last and is formed in three sections (Figure 6).

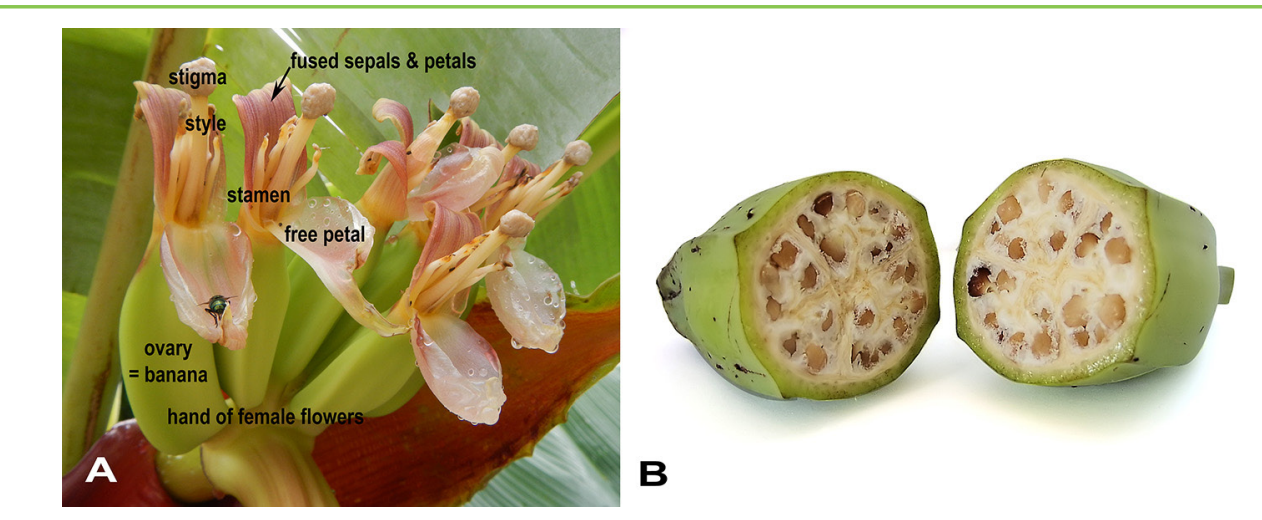

Figure 3 
Figure 4

(A) A flower cluster of the hairy banana with hands of female flowers below hands of male flowers. Unlike supermarket bananas, the flowers point upright in this species (compare Figure $1 B$ with Figure 4A).

(B) A mature female flower of the hairy banana. The ovary of the female flowers becomes the banana. Scale bar = 0.4 inches. (C) A cluster of banana flowers with one hand of young female flowers shown. As they form, the hands of flowers are wrapped in modified leaves. Scale bar $=0.02$ inches. (D) A hand of flowers like the one shown in (E). The sepals, petals, stamens, and ovary are all formed on the young flower. (E) A hand of young flowers with the flower parts labeled. The cup grows and eventually forms the ovary and later the banana fruit. $\mathrm{s}=$ stamen Scale bar $=0.02$ inches.

\section{OVARY}

The part of the flower that forms the fruit. The ovary contains the egg just like the fruit contains the seed. The Greek root ov- means egg, but this is tricky because the ovary is not the egg. The egg is inside the ovary.

\section{POLLEN (OR POLLEN GRAINS)}

Pollen grains contain sperm cells that fuse with the egg to produce the next generation of plants. The Latin word pollen means "fine flour." You may have seen pollen on the ground (or on someone's car) in the spring, when the pollen is released. It looks like flour.

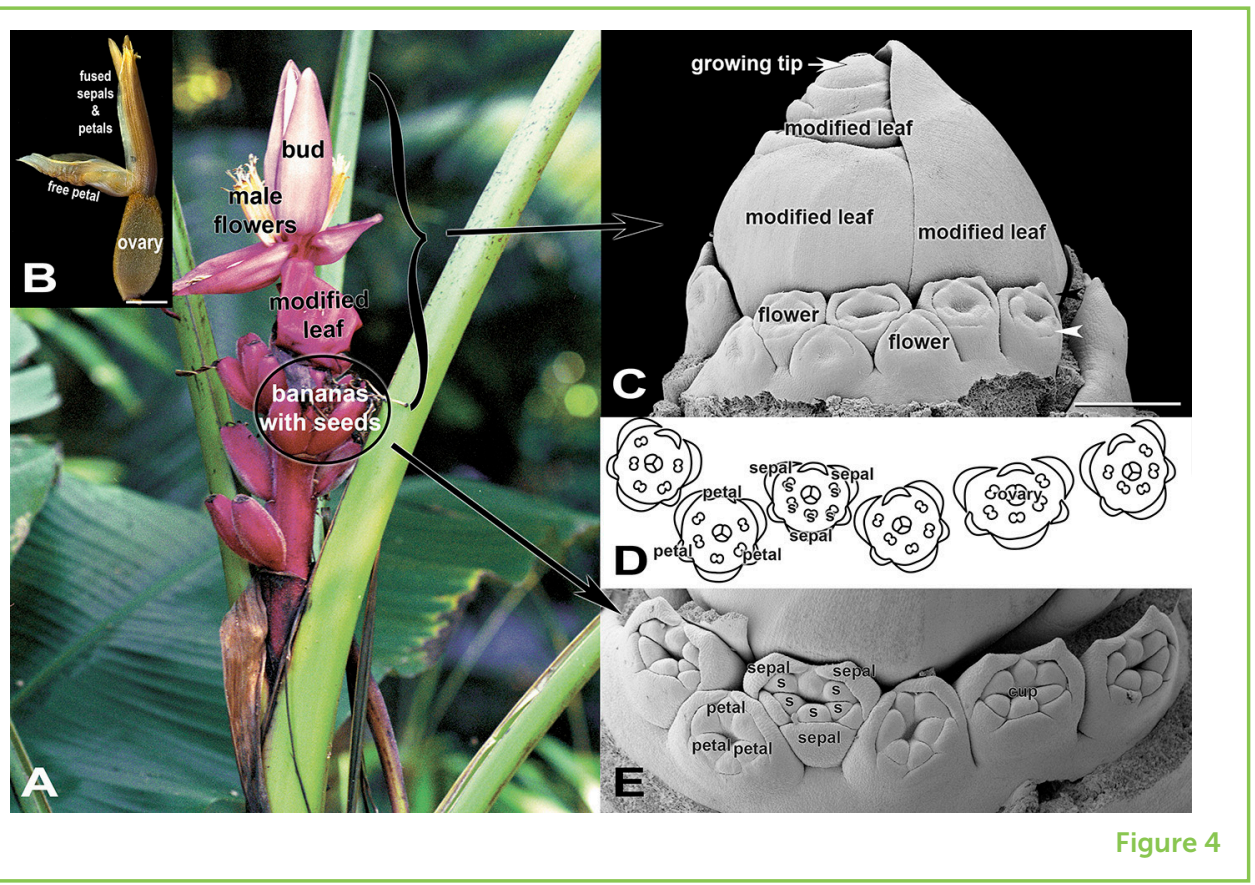

As the first two sepals form, they change the shape of the young flower, so that it becomes triangular (Figure 5C). The other flower parts form inside the sepals. The first petal then appears (Figure 5E), followed by the three outer stamens (Figures 5F,G white arrows), then the two other petals and their closest stamens (Figures $5 \mathrm{H}, \mathrm{I}$ ). The ovary forms last (Figures 6A-D). In flowers like the banana, with the ovary below the other flower parts (Figure 3A), the sections of the ovary form from the sides of a cup-like hole at the center of the flower (Figures 5K,L, 6A-C).

While there are important differences between female and male flowers, both types of flowers produce their parts in similar ways. The differences that do occur do not result in differences between the mature flowers. For example, in male flowers, the side of the flower that is next to the modified leaves (Figure 4, white arrowhead) develops slightly ahead of the side that is away from these leaves (Figure 4, black arrowhead), whereas in female flowers, the opposite is true. These differences disappear by the time the female parts of the flower form, and are not visible in the mature flowers.

\section{EXPLORING FLOWER DEVELOPMENT}

We have created an exercise that will help you better understand how banana flowers develop. This exercise is very similar to the way scientists study flower development. We can almost never watch a single flower develop over time because we have to destroy parts of the plant to see the young flowers. Although we cannot watch the development of a 


\section{Figure 5}

The formation of the flower parts can be seen in these pictures of young flowers of the hairy banana. A whole flower cluster, like that shown in Figure $4 \mathrm{~A}$, is shown in (A). Each following picture (B-M) shows a stage of formation of the flower parts. The colors and letters were added to help match the flowers in $(\mathbf{B}-\mathbf{M})$ to their location in (A). The flower organs (sepals, petals, and stamen) are labeled to show the order in which they are formed. $\mathrm{s}=$ stamen. All scale bars $=0.002$ inches.

\section{SCANNING}

\section{ELECTRON}

\section{MICROSCOPE}

\section{(OFTEN}

\section{ABBREVIATED SEM)}

A powerful microscope that uses electrons instead of light to produce images. SEMs allow scientists to see small structures much more clearly than they can using light microscopes.

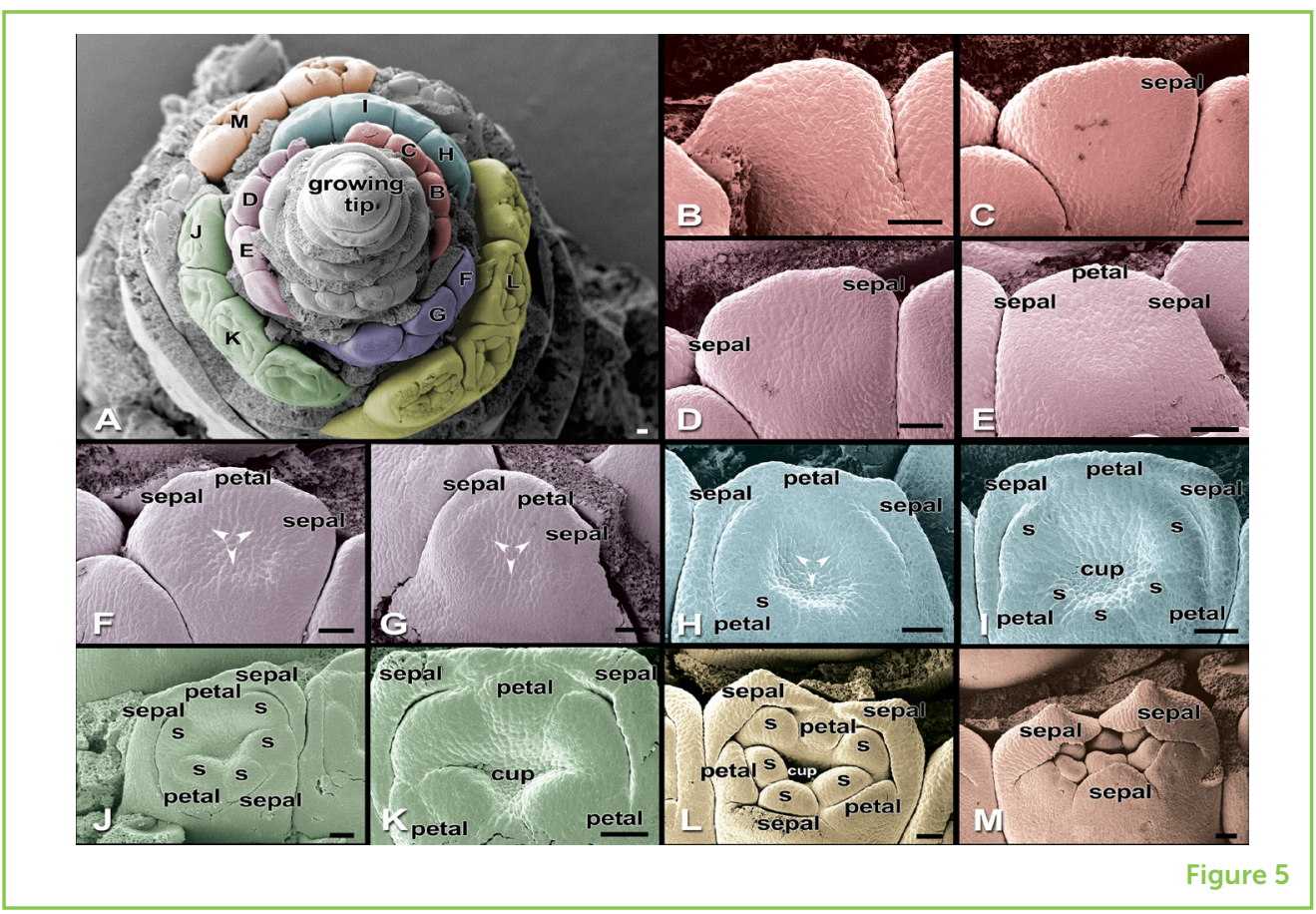

single flower, we can re-create this development by taking pictures of different young flowers and arranging the pictures in order. We have taken the pictures for you. Now you have to arrange them in the correct order. Do not worry, we will give you some help.

We will start with images that are similar to those used in this paper. Download and print the pictures in the file Musa velutina-Full size.pdf, then cut the images apart. These images came directly from a very powerful microscope called a scanning electron microscope. You will see that there is a small number on the lower left corner of each photograph. You will use these numbers to check your answer once you have placed the photographs in order. Try it!

If you find this task too difficult or if you want to check your work before looking at the key, then you can print a set of correctly sized photographs. The file Musa velutina-Resized.pdf has the same photographs, but the photos have been sized so that the younger flowers are smaller than the older flowers. It will be easier for you to determine the correct order with these images because you can use size as a guide. However, be careful! The size of a young flower is not always a perfect guide to its stage of development. Some of the photographs that look larger may actually show flowers at younger stages.

When you are ready to check your work, print the file Musa velutinaKey.pdf and compare the order of the photographs to the order that you have created. If your results do not agree with the key, you can 


\section{Figure 6}

(A-C) The female part of the flower forms last, in three sections (1-3), around the edge of the cup at the center of the flower. The three sections grow downward into the cup to form the ovary, and upward to close the ovary. (D) The closure of the ovary is shown here, just as the three sections are growing together. All scale bars $=0.002$ inches

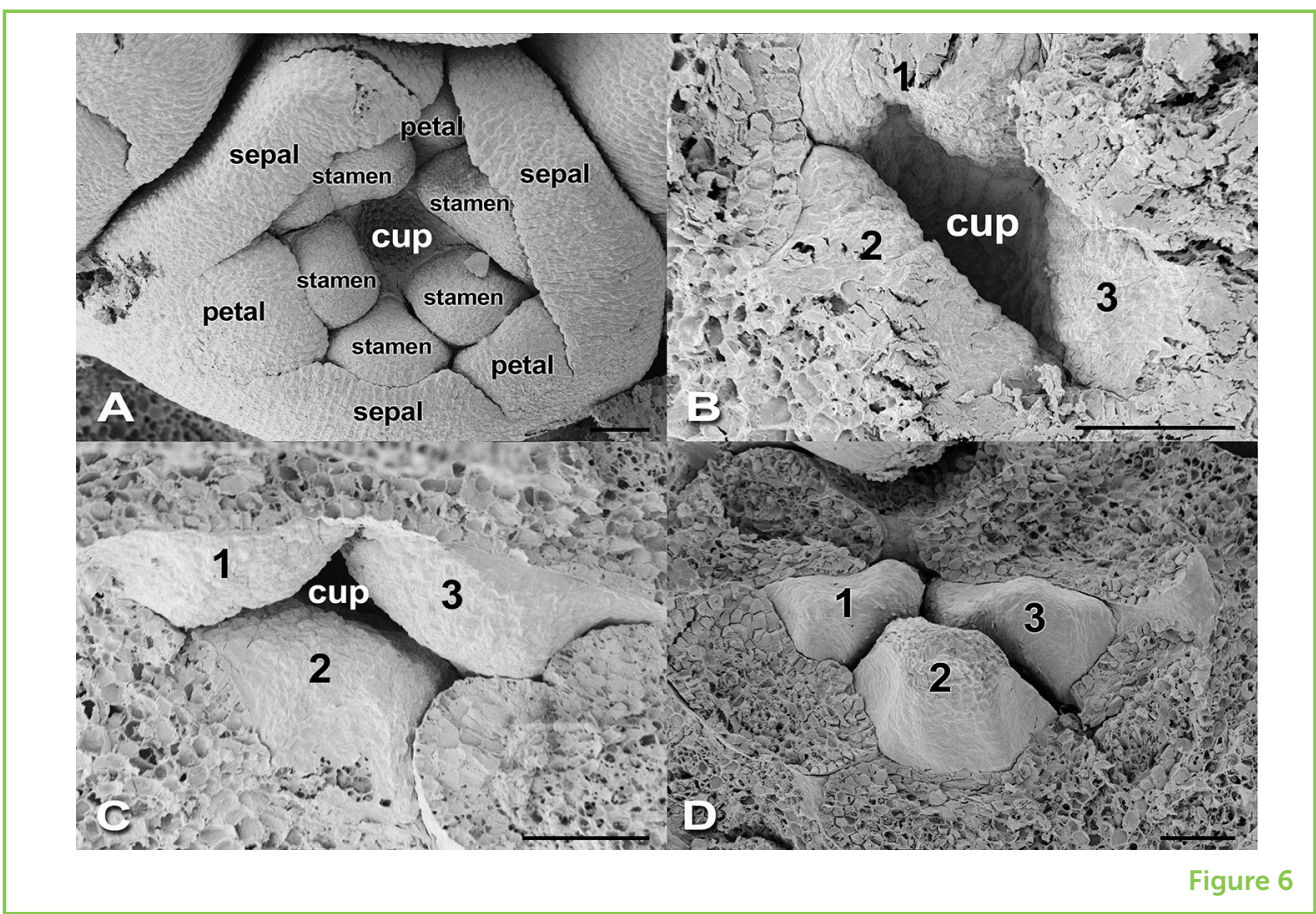

try sorting the photographs again. Scientists often arrange images like these many times before they are satisfied with the result.

If you would like to continue your explorations, then you can download and work with the full set of photographs that were used in this research. There are 644 photographs organized into folders based on the flowering branch they come from. Follow this link to download all the photographs.

Now that you have more experience looking at the stages of flower development, go back to Figure 5 and compare what you see there to your work, and to the key. You can probably see some of the differences in flower development that cannot easily be described in words. For instance, the formation of the sepals usually cause the developing flower to becomes triangular, but sometimes it has a slightly more rounded shape (compare Figures 5F and G). Many other slight differences are visible in Figure 5. What else do you notice? You are on your way to becoming a scientist!

\section{IMAGE LICENSES}

Figure 1A: Musa_acuminata_X_balbisiana_01.jpg by Wikimedia Commons contributors licensed under CC BY-SA 3.0 (https://creativecommons.org/licenses/by-sa/3.0/us/). The image was cropped, and text was added. Figure 1B: M. acuminata $x$ balbisiana.jpg by Wikimedia 
Commons contributors licensed under CC BY-SA 2.5 (https://creativecommons.org/licenses/by-sa/2.5/). The image was cropped, and text was added. Figure 2A: Drawings modified after [2], used with permission. Figure 2B: Original drawings. Figure 3A: 0794jfBuliran_San_Fernando_ Bananas_River_Sur_Cabiao_Ecijafvf_08.jpg by Creative Commons Attribution-ShareAlike 3.0 Unported, 2.5 Generic, 2.0 Generic and 1.0 Generic license (https://creativecommons.org/licenses/by-sa/3.0/deed. en). The image was cropped, and text was added. Figure 3B: Inside_a_ wild-type_banana.jpg-GNU by Free Documentation License, Version 1.2 (https://www.gnu.org/licenses/old-licenses/fdl-1.2.en.html). The background of the image was lightened, and the image was cropped. Figures 4-6: All photographs are original.

\section{ACKNOWLEDGMENTS}

Max Dulin, Tam Le, Allyson Prevette, Sonja Cauble, Elizabeth Shelton, and Kimberly Hamlet took photographs and helped determine the pattern of flower formation as part of their undergraduate research. Ross Cangelosi created the colored images used in Figure 5 as part of his work for an independent study in the UNC Greensboro Department of Art. I am grateful to his instructor, Dr. Amy Lixl-Purcell, for sponsoring his work.

\section{ORIGINAL SOURCE ARTICLE}

Kirchoff, B. K. 2017. Inflorescence and flower development in Musa velutina $\mathrm{H}$. Wendl. \& Drude (Musaceae), with a consideration of developmental variability, restricted phyllotactic direction, and hand initiation. Int. J. Plant Sci. 178:259-72. doi: $10.1086 / 691143$

\section{REFERENCES}

1. Food and Agricultural Organization of the United Nations. 2018. Banana facts and figures. http://www.fao.org/economic/est/est-commodities/bananas/ bananafacts/en/\#.W9tvrJNKiUI

2. Fahn, A. 1953. The origin of the banana inflorescence. Kew Bull. 8:299-306.

3. Kirchoff, B. K., Lagomarsino, L. P., Newman, W. H., Bartlett, M. E., and Specht, C. D. 2009. Early floral development of Heliconia latispatha (Heliconiaceae), a key taxon for understanding the evolution of flower development in the Zingiberales. Am. J. Bot. 96:580-93. doi: 10.3732/ajb.0800305

4. Kirchoff, B. K. 2003. Shape matters: Hofmeister's rule, primordium shape, and flower orientation. Int. J. Plant Sci. 164:505-17. doi: 10.1086/375421 
SUBMITTED: 12 December 2017; ACCEPTED: 16 October 2018; PUBLISHED ONLINE: 20 November 2018.

EDITED BY: Chelsea D. Specht, Cornell University, United States

CITATION: Kirchoff BK and Bruenn RA (2018) How do Banana Flowers Develop? Front. Young Minds 6:60. doi: 10.3389/frym.2018.00060

CONFLICT OF INTEREST STATEMENT: The authors declare that the research was conducted in the absence of any commercial or financial relationships that could be construed as a potential conflict of interest.

COPYRIGHT @ 2018 Kirchoff and Bruenn. This is an open-access article distributed under the terms of the Creative Commons Attribution License (CC BY). The use, distribution or reproduction in other forums is permitted, provided the original author(s) and the copyright owner(s) are credited and that the original publication in this journal is cited, in accordance with accepted academic practice. No use, distribution or reproduction is permitted which does not comply with these terms.

\section{YOUNG REVIEWER}

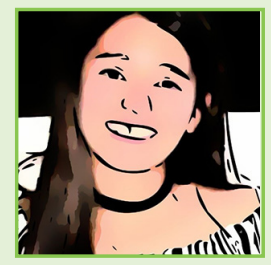

\section{SOFÍA, AGE: 14}

My favorite thing to do is to travel. For my future career, I would like to study modern languages and that way I could visit a lot of places around the world.

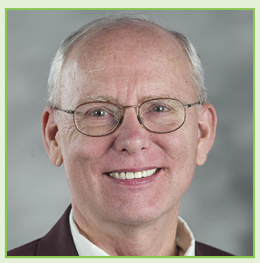

\section{AUTHORS}

\section{BRUCE K. KIRCHOFF}

I am a botanist and professor of biology at the University of North Carolina at Greensboro. I study the evolution of flower development in tropical gingers and bananas. This group contains eight families of plants and about 2,600 species. I think that it is important to understand how plants develop, because it gives us insight into the forms of life that we see around us. The patterns we see are also very beautiful. I hope you will agree. The study of development can help us better understand how these plants came into being through evolution. *kirchoff@uncg.edu

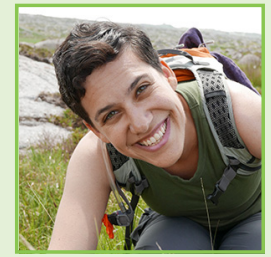

\section{RIVA A. BRUENN}

I teach biology to college students. As a scientist I studied the genes that affect whether flowers have one line of symmetry, like a face, or many lines, like a circle. I am interested in how flowers develop and in the evolution of plants. In my free time, I like to hike, go camping, and crochet. 